\title{
ANALISIS FAKTOR-FAKTOR YANG MEMPENGARUHI PENGAMBILAN KEPUTUSAN PEMBERIAN KREDIT PADA PD. BPR. BANK DAERAH LAMONGAN
}

\author{
Nidia Roudhotul Nur Jannah ${ }^{1}$ \\ Fakultas Ekonomi, Universitas Islam Lamongan \\ nidiar1310@gmail.com \\ Pudiastiono $^{2}$ \\ Fakultas Ekonomi, Universitas Islam Lamongan \\ pudiaston@yahoo.co.id \\ Ruswaji ${ }^{3}$ \\ Fakultas Ekonomi, Universitas Islam Lamongan \\ ruswaj11965@gmail.com
}

\begin{abstract}
Abstrak
Dunia perbankan merupakan salah satu lembaga keuangan yang mempunyai nilai strategis dalam kehidupan perekonomian suatu negara. Bank sebagai lembaga keuangan juga bekerja berdasarkan kepercayaan masyarakat.

Berdasarkan uraian di atas, penulis mengangkat masalah dalam penelitian ini adalah analisis faktor Character, Capacity, Capital, Collateral, Condition Of. Economy, Constraints dalam pemberian kredit PD. BPR. Bank Daerah Lamongan.
\end{abstract}

Dalam analisis data, penulis menggunakan metode survey. Hasil analisa datanya :menentukan metode uji validitas : variabel bebas dan terikat nilai Sig (2-tailed) $<p=0.05$, uji reliabilitas : nilai alpha variable bebasnya lebih besar dari 0,6 dengan tingkat signifikan $\alpha=5 \%$ sehingga dapat disimpulkan bahwa instrumen dalam variabel bebas dan terikatnya realibel, regresi linier berganda: $Y=9,188+0,075 X_{1}+0,484 X_{2}+0,682 X_{3}+0,269 X_{4}+0,695 X_{5}+$ $0,958 X_{6}$, koefisien korelasi : $(R)$ sebesar 0,486,koefisien determinasi : variable bebas terhadap variable terikatnya sebesar 0,237 \% ,uji t nya variable constraints adalah berpengaruh yang tidak signifikan.

Dari analisa statistik yang dilakukan dapat diambil suatu kesimpulan. Analisis faktor 6C yang mempengaruhi pemberian kredit pada PD. BPR. Bank Daerah Lamongan masuk dalam kategori baik. Faktor 6C berpengaruh yang signifikan terhadap pengambilan keputusan dalam memberikan kredit pada PD. BPR. Bank Daerah Lamongan. Faktor Constraints yang paling berpengaruh terhadap pemberian kredit pada PD. BPR. Bank Daerah Lamongan.

Kata kunci : faktor $6 C(X)$ dan pemberian kredit $(Y)$ 


\section{PENDAHULUAN}

\section{Latar Belakang}

$$
\text { Seiring perkembangan }
$$

perekonomian Indonesia sekarang ini memerlukan keadaan ekonomi yang stabil yang akan membantu memperlancar usaha pemerintah dalam mengadakan perhitungan perencanaan pembangunan. Kondisi ekonomi yang stabil memudahkan pemerintah mengadakan evaluasi serta ramalan dalam menyusun rencana pembangunan. Dengan kondisi perekonomian yang stabil ini diharapkan agar perhitunganperhitungan dalam perencanaan tidak akan mengalami banyak penyimpangan dalam pelaksanaannya. Untuk mencapai suatu keadaan perekonomian yang stabil pertama-tama perlu diusahakan suatu kondisi moneter yang mantap, kondisi tersebut akan tercapai apabila ditunjang oleh sistem perbankan yang sehat dan sempurna.

Bank dalam menjalankan usahanya menghimpun dana masyarakat dan menyalurkannya kembali dalam berbagai alternative investasi. Sehubungan dengan fungsi penghimpun dana ini, bank sering pula disebut dengan lembaga kepercayaan. Berbeda halnya dengan perusahaan lainnya, transaksi usaha bank senantiasa berkaitan dengan uang, karena memang komoditi usaha bank adalah uang. Sejalan karakteristik usahanya tersebut maka, bank merupakan suatu segmen usaha yang kegiatannya banyak diatur oleh pemerintah.

Dalam pemberian kredit, setiap bank menggunakan analisis kredit atau penilaian kredit karena analisis kredit merupakan suatu proses yang dimaksudkan menganalisa atau menilai suatu permohonan kredit yang dijadikan oleh calon debitur kredit sehingga dapat memberikan keyakinan kepada pihak bank bahwa proyek atau usaha yang akan dibiayai dengan kredit bank cukup layak (feasible).

\section{METODELOGI}

Penelitian ini menggunakan penelitian kuantitatif adalah jenis penelitian yang menghasilkan penemuan-penemuan yang dapat dicapai (diperoleh) dengan menggunakan prosedur-prosedur statistic atau cara-cara lain dari kuantifikasi (pengukuran). Pendekatan kuantiatf memusatkan perhatian pada gejala-gejala yang 
mempunyai karakteristik tertentu di dalam kehidupan manusia yang dinamakannya sebagai variabel. Dalam pendekatan kuantitatif hakekat hubungan di antara variabelvariabel dianalisis dengan menggunakan teori yang obyektif.

Data karyawan PD. BPR. Bank Daerah Lamongan yang digunakan dalam penelitian. Data penenlitian ini bersumber dari PD. BPR. Bank Daerah Lamongan. Data kuisioner yang digunakan dalam penelitian. Data ini bersumber dari jawaban responden karyawan PD. BPR. Bank Daerah Lamongan..

Persamaan dan perbedaan data statistic yang di peroleh dri jurnal penelitian Budi Setiawan, Yeni Maulina, Ahmad Muntolib dapat memberikan informasi dan kemajuan penelitian dari permasalahan antara faktor-faktor yang mempengaruhi pemberian kredit dapat disimpulkan dalam rumus sebagai berikut :

$\mathrm{Y}=\mathrm{a}+\mathrm{b} 1 . \mathrm{X} 1+\mathrm{b} 2 . \mathrm{X} 2+\mathrm{b3.X} 3+$ b4.X4 + b5.X5 + b6.X6 + e

Dimana dapat disimpulkan $\mathrm{Y}=$ Variabel dependen (Kinerja Karyawan), a = Konstanta, b1,b2 = Koefisien garis regresi, X1, X2 =
Variabel independen, e $=$ Error $/$ variabel pengganggu.

\section{ANALISIS DAN PEMBAHASAN}

Adapun analisis data yang di gunakan dalam perhitungan adalah sebagai berikut :

1. Uji Validitas,

2. Uji Reliabilitas,

3. Uji Regresi Linier Berganda,

4. Koefisien Korelasi,

5. Koefisien Determinasi,

6. Uji t,

7. Uji F.

Analisisnya sebagai berikut : 
Tabel 1

Uji Validitas

\begin{tabular}{|c|c|c|c|c|}
\hline No & $\begin{array}{c}\text { Indikator } \\
\text { Pertyanyaan }\left(\mathrm{X}_{1}\right)\end{array}$ & $\begin{array}{c}\text { Angka Korelasi } \\
\text { rhitung }\end{array}$ & $\begin{array}{c}\text { Angka Korelasi } \\
\text { rtabel }\end{array}$ & Keterangan \\
\hline 1 & Latar belakang & 0,374 & 0,201 & Valid \\
\hline 2 & Dipercaya & 0,562 & 0,201 & Valid \\
\hline 3 & Ketrampilan & 0,401 & 0,201 & Valid \\
\hline No & $\begin{array}{c}\text { Indikator } \\
\text { Pertyanyaan }\left(\mathbf{X}_{2}\right)\end{array}$ & $\begin{array}{c}\text { Angka Korelasi } \\
\text { rhitung }\end{array}$ & $\begin{array}{c}\text { Angka Korelasi } \\
\mathbf{r}_{\text {tabel }}\end{array}$ & Keterangan \\
\hline 1 & Nasabah & 0,278 & 0,201 & Valid \\
\hline 2 & Dana & 0,494 & 0,201 & Valid \\
\hline 3 & Kredit & 0,392 & 0,201 & Valid \\
\hline No & $\begin{array}{c}\text { Indikator } \\
\text { Pertyanyaan }\left(\mathrm{X}_{3}\right)\end{array}$ & $\begin{array}{c}\text { Angka Korelasi } \\
\text { rhitung }\end{array}$ & $\begin{array}{c}\text { Angka Korelasi } \\
\text { rtabel }\end{array}$ & Keterangan \\
\hline 1 & Pendapatan & 0,496 & 0,201 & Valid \\
\hline 2 & Laba & 0,400 & 0,201 & Valid \\
\hline 3 & Modal usaha & 0,307 & 0,201 & Valid \\
\hline No & $\begin{array}{c}\text { Indikator } \\
\text { Pertyanyaan }\left(\mathrm{X}_{4}\right)\end{array}$ & $\begin{array}{c}\text { Angka Korelasi } \\
\text { rhitung }\end{array}$ & $\begin{array}{c}\text { Angka Korelasi } \\
\text { rtabel }\end{array}$ & Keterangan \\
\hline 1 & Jaminan & 0,582 & 0,201 & Valid \\
\hline 2 & Calon nasabah & 0,587 & 0,201 & Valid \\
\hline 3 & Jangka waktu & 0,456 & 0,201 & Valid \\
\hline No & $\begin{array}{c}\text { Indikator } \\
\text { Pertyanyaan }\left(\mathrm{X}_{5}\right)\end{array}$ & $\begin{array}{c}\text { Angka Korelasi } \\
\text { rhitung }\end{array}$ & $\begin{array}{c}\text { Angka Korelasi } \\
\mathbf{r}_{\text {tabel }}\end{array}$ & Keterangan \\
\hline 1 & Kondisi ekonomi & 0,509 & 0,201 & Valid \\
\hline 2 & Informasi & 0,590 & 0,201 & Valid \\
\hline 3 & Pengaruh & 0,594 & 0,201 & Valid \\
\hline No & $\begin{array}{c}\text { Indikator } \\
\text { Pertyanyaan }\left(\mathbf{X}_{6}\right)\end{array}$ & $\begin{array}{c}\text { Angka Korelasi } \\
\text { rhitung }\end{array}$ & $\begin{array}{c}\text { Angka Korelasi } \\
\text { rtabel }\end{array}$ & Keterangan \\
\hline 1 & Hambatan/rintangan & 0,559 & 0,201 & Valid \\
\hline 2 & Lokasi & 0,454 & 0,201 & Valid \\
\hline 3 & Prinsip & 0,285 & 0,201 & Valid \\
\hline No & $\begin{array}{c}\text { Indikator } \\
\text { Pertyanyaan }(\mathbf{Y})\end{array}$ & $\begin{array}{c}\text { Angka Korelasi } \\
\text { rhitung }\end{array}$ & $\begin{array}{c}\text { Angka Korelasi } \\
\text { rtabel }\end{array}$ & Keterangan \\
\hline 1 & Bunga jaminan & 0,253 & 0,201 & Valid \\
\hline 2 & Jangka waktu & 0,448 & 0,201 & Valid \\
\hline 3 & Sumber dana & 0,383 & 0,201 & Valid \\
\hline
\end{tabular}

Sumber : Lampiran, perhitungan SPSS - Validitas

Dari table di atas dapat di simpulkan bahwa semua variabel adalah valid, hal ini di buktikan dengan nilai masing-masing item 
$\begin{array}{llll}\mathrm{r}_{\text {hitung }}>\mathrm{r}_{\text {tabel. }} . & \begin{array}{l}\text { Sehingga } \\ \text { gunakan }\end{array} & \begin{array}{c}\text { dapat di } \\ \text { dalam }\end{array} & \text { pengujian }\end{array}$

Tabel 2

Uji Reliabilitas

\begin{tabular}{|l|c|c|}
\hline \multicolumn{1}{|c|}{ Variabel } & Nilai Alpa & Keterangan \\
\hline Character $\left(\mathrm{X}_{1}\right)$ & 0,633 & Reliabel \\
\hline Capacity $\left(\mathrm{X}_{2}\right)$ & 0,572 & Reliabel \\
\hline Capital $\left(\mathrm{X}_{3}\right)$ & 0,588 & Reliabel \\
\hline Collateral $\left(\mathrm{X}_{4}\right)$ & 0,716 & Reliabel \\
\hline $\begin{array}{l}\text { Condition Of Economy } \\
\left(\mathrm{X}_{5}\right)\end{array}$ & 0,732 & Reliabel \\
\hline Constraints $\left(\mathrm{X}_{6}\right)$ & 0,617 & Reliabel \\
\hline Pemberian Kredit $(\mathrm{Y})$ & 0,546 & Reliabel \\
\hline
\end{tabular}

Sumber : Lampiran, perhitunganSPSS - Reliabilitas

Dari tabel di atas, nilai Alpha variabel bebas dan terikatnya, yaitu character, capacity, capital, condition of economy lebih kecil dari 0,6 sedangkan collateral, constraints dan pemberian kredit lebih besar dari 0,6 dengan tingkat signifikan $\alpha=5 \%$ sehingga dapat disimpulkan bahwa instrumen dalam variabel bebas dan terikatnya realibel.

Tabel 3

Uji Regresi Linier Berganda

\begin{tabular}{|c|c|c|c|}
\hline Variabel & Koefisien Regresi & thitung & Sig. \\
\hline Character (X1) & 0,075 & 0,575 & 0,568 \\
\hline Capacity (X2) & 0,484 & 1,914 & 0,059 \\
\hline Capital (X3) & 0,683 & 2,689 & 0,009 \\
\hline Collateral (X4) & 0,269 & 4,007 & 0.000 \\
\hline Condition Of Economy (X5) & 0,695 & 1,892 & 0,062 \\
\hline Constraints (X6) & 0,958 & 2,468 & 0,015 \\
\hline Konstanta $\quad: 9,188$ & & $F_{\text {hitung }}: 4,802$ & \\
\hline $\mathrm{R} \quad: 0,201$ & & Sig $\quad: 0,000$ & \\
\hline $\mathrm{R}_{\text {Square }} \quad: 0,237$ & & & \\
\hline
\end{tabular}

Sumber : Lampiran, perhitungan SPSS 
Dari perhitungan regresi pengambilan keputusan pemberian linier berganda di atas dapat di kredit di PD. BPR. Bank Daerah simpulkan bahwa variabel character Lamongan, variabel Collateral $\left(\mathrm{X}_{4}\right)=$ $\left(\mathrm{X}_{1}\right)=0,075$ atau $0,75 \%$ yang artinya 0,269 atau $26,9 \%$ yang artinya variabel character $\left(\mathrm{X}_{1}\right)$ mempunyai pengaruh positif terhadap pengambilan keputusan pemberian kredit di PD. BPR. Bank Daerah Lamongan, variabel Capacity $\left(\mathrm{X}_{2}\right)=$ 0,484 atau $48,4 \%$ yang artinya variabel Capacity $\left(\mathrm{X}_{2}\right)$ mempunyai pengaruh positif terhadap pengambilan keputusan pemberian kredit di PD. BPR. Bank Daerah Lamongan, variabel Capital $\left(\mathrm{X}_{3}\right)=$ 0,683 atau $68,3 \%$ yang artinya variabel Capital $\left(\mathrm{X}_{3}\right)$ mempunyai variabel Collateral $\left(\mathrm{X}_{4}\right)$ mempunyai pengaruh positif terhadap pengambilan keputusan pemberian kredit di PD. BPR. Bank Daerah Lamongan, variabel Condition Of Economy $\left(X_{5}\right)=0,695$ atau $69,5 \%$ yang artinya variabel Condition Of Economy $\left(\mathrm{X}_{5}\right)$ mempunyai pengaruh positif terhadap pengambilan keputusan pemberian kredit di PD. BPR. Bank Daerah Lamongan, variabel Constraints $\left(\mathrm{X}_{6}\right)=0,958$ atau $95,8 \%$ pengaruh positif terhadap

Tabel 4

Koefisien Korelasi

\begin{tabular}{|c|c|c|}
\hline No & Keterangan & Nilai \\
\hline 1 & Nilai Koefisien Korelasi & 0,486 \\
\hline
\end{tabular}

Sumber : Lampiran, perhitungan SPSS

Dari Tabel di atas dapat pemberian kredit adalah sebesar diketahui bahwa koefisien korelasi 0,486 . Sesuai dengan tabel korelasi antara variabel character, capacity, dapat disimpulkan bahwa hubungan capital, collateral, condition of antara variabel sangat kuat.

economy dengan variabel terikatnya 
Tabel 5

Koefisien Determinasi

\begin{tabular}{|c|c|c|}
\hline No & Keterangan & Nilai \\
\hline 1 & Nilai Koefisien Determinasi & 0,237 \\
\hline
\end{tabular}

Sumber : Lampiran, perhitungan SPSS

Dari tabel diatas diperoleh koefisien determinasi $\left(\mathrm{R}^{2}\right)$ yaitu sebesar 0,237. Dari nilai $R^{2}$ tersebut dapat ditarik kesimpulan bahwa variabel character, capacity, capital, collateral, condition of economy dan constraints secara bersama sama telah mampu menjelaskan atau menerangkan keragaman dari variabel terikat yaitu pemberian kredit. Pengaruh variabel character, capacity, capital, collateral, condition of economy dan constraints terhadap pemberian kredit (Y) memberikan kontribusi sebesar 23,7 \%, sedangkan sisanya sebesar $76,3 \%$ merupakan faktor lain. Sisanya lebih besar dikarenakan permasalahan di perusahaan sangat komplek.

Tabel 6

\begin{tabular}{|l|c|c|c|}
\multicolumn{1}{|c|}{ Uariabel } & thitung & t tabel & Keterangan \\
\hline Character (X1) & 0,575 & 1,661 & Tidak Signifikan \\
\hline Capacity (X2) & 1,914 & 1,661 & Signifikan \\
\hline Capital (X3) & 2,659 & 1,661 & Signifikan \\
\hline Collateral (X4) & 4,007 & 1,661 & Signifikan \\
\hline Condition Of Economy (X5) & 1,892 & 1,661 & Signifikan \\
\hline Constraints (X6) & 2,468 & 1,661 & Signifikan \\
\hline
\end{tabular}

Sumber : Lampiran, Perhitungan SPSS - Regresi

Dari hasil uji t diperoleh nilai yang berarti bahwa variabel bebas

t hitung Character 0,575, Capacity

Capacity, Capital, Collateral,

1,914, Capital 2,659, Collateral

Condition Of Economy dan

4,007, Condition of economy 1,892 ,

Constraints mempunyai pengaruh

Constraint 2,468. Tidak semua yang signifikan terhadap pemberian variabel bebas mempunyai nilai $\mathrm{t}$ kredit terkecuali variabel bebas hitung yang lebih besar dari t tabel Character. 


\section{Tabel 6}

Uji F

\begin{tabular}{|c|c|c|}
\hline No & Keterangan & Nilai \\
\hline 1 & Nilai Uji F & 4,802 \\
\hline
\end{tabular}

Sumber : Lampiran SPSS

Dari hasil pengujian uji $\mathrm{F}$ terdapat tabel regresi bergandadiperoleh $F_{\text {hitung }}$ sebesar 4,802. Sedangkan $F_{\text {tabel }}$ sebesar 3,09. Karena $F_{\text {hitung }}>F_{\text {tabel }}$ maka $\mathrm{H}_{\mathrm{o}}$ ditolak artinya bahwa variabel bebas (Character, Capacity, Capital, Collateral, Condition Of Economy, Constraints) secara bersama- sama mempunyai pengaruh yang signifikan terhadap pemberian kredit.

\section{KESIMPULAN}

Hasil pengelolaan data diperoleh nilai $\mathrm{t}$ hitung character 0,575 , capacity 1,914 , capital 2,659 , collateral 4,007, condition of economy 1,892 , constraint 2,468 . Tidak semua variabel bebas mempunyai nilai t hitung yang lebih besar dari t tabel yang berarti bahwa variabel bebas Capacity, Capital, Collateral, Condition Of Economy terdapat tabel regresi bergandadiperoleh $F_{\text {hitung }}$ sebesar 4,802. Sedangkan $F_{\text {tabel }}$ sebesar 3,09. Karena $F_{\text {hitung }}>\mathrm{F}_{\text {tabel }}$ maka $\mathrm{H}_{\mathrm{o}}$ ditolak artinya bahwa variabel bebas (Character, Capacity, Capital, Collateral, Condition Of Economy, Constraints) secara bersama- sama mempunyai pengaruh yang signifikan terhadap pemberian kredit. Hasil dari regresi linear berganda diperoleh persamaan, $\mathrm{Y}=$ $9,188+0,075 \mathrm{X}_{1}+0,484 \mathrm{X}_{2}+$ $0,682 X_{3}+0,269 X_{4}+0,695 X_{5}+$ $0,958 \mathrm{X}_{6}$. Dari perhitungan tersebut, dapat diketahui bahwa variabel Constraintsyang berpengaruh paling dominan terhadap pengambilan keputusan pemberian kredit karena variabel Constraints $\left(\mathrm{X}_{6}\right)$ memiliki nilai yang besar dari variabel bebas yang lain.

dan Constraints mempunyai pengaruh yang signifikan terhadap pemberian kredit terkecuali variabel bebas Character. 


\section{DAFTAR PUSTAKA}

Arikunto Suharsimi,2002, Prosedur Penelitian, Cetakan keduabelas, penerbit Rineka Cipta Jakarta

Dendawijaya, Lukman,2003, Manajemen Perbankan, Cetakan kedua. Penerbit Ghalia, Indonesia Kasmir, 2002. Bank dan lembaga keuangan lainnya, cetakan keenam, penerbit. PT. Raja Grafindo Persada Jakarta

Muljono Pudjo Teguh, 2001 Manajemen Perkreditan bagi bank komersial,edisi empat, Cetakan pertama, penerbit BPFE Yogyakarta

Nazir, Mohammad, 2005. Metode penelitian, cetakan keenam. Penerbit. Ghalia Indonesia. Ciawi Bogor Selatan

Siamat Dahlan, 1995. Manajemen Lembaga Keuangan, Cetakan pertama Penerbit. CV. intermedia Jakarta

Sugiyono. 2014. Metode Penelitian Kuantitatif, kualitatif, dan $R \& D$.

Bandung

Penerbit Alfabeta

Sujarweni, 2014. SPSS Untuk Penelitian, Cetakan Pustaka Baru
Sumarul Murti dan Soeprihanto Jhon, 1998, pengantar bisnis, cetakan pertama. Penerbit. Liberty Yogyakarta

Suyatno, Thomas 1991. Dasar perkreditan, Edisi kedua, cetakan keempat. Penerbit. PT. Gramedia Pustaka Utama, Jakarta

Zuhri. Syaifuddin, Metodologi Penelitian, UNIDA Press, Jakarta, 2001 